\title{
Relationship between the nutritional state before the breeding period and the reproductive success in alpacas (Vicugna pacos) from the Chilean Puna
}

\author{
Cecilia Norambuena ${ }^{\mathrm{a}, \mathrm{b}, *}$, Francisca Hernández ${ }^{\mathrm{a}}$, Jorge Alfaro ${ }^{\mathrm{a}}$, Gustavo Cárcamo ${ }^{\mathrm{a}}$, \\ Ángela Olavarría ${ }^{a}$, Miriam Velasco $^{a}$
}

\begin{abstract}
A poor nutritional state may explain the low fertility rates of domestic camelids from Puna herds. The objective of this study was to determine the relationship between the nutritional state of alpacas before the breeding period and their reproductive success. The body live weight (BLW) and body condition score (BCS; scale from 1-5) of 35 non-pregnant non-lactating alpacas from the Caquena bofedal in Chile were registered previous to the breeding period. In addition, blood samples were collected (heparinised tubes) to determine the plasma concentration of cholesterol (CHOD-PAP method), triglycerides (GPO-PAP method) and NEFA (enzymatic colorimetric method). Pregnancy was determined by trans-rectal ultrasonography (7.5 MHz, Samsung Madison, Korea) at the end of the breeding period. Data from Pregnant and Non-Pregnant groups were compared using Mann-Whitney U test (SPSS programme; $P<0.05)$. Pregnant $(\mathrm{n}=20)$ and Non-pregnant groups $(\mathrm{n}=15)$ had similar BLW $(47.1 \pm 8.8$ compared to $52.8 \pm 11.1 \mathrm{~kg}$, respectively; $P=0.9)$, BCS $(3.0 \pm 0.4$ compared to $3.1 \pm 0.4$, respectively; $P=0.5)$, plasma cholesterol $(1.0 \pm 0.4$ compared to $0.9 \pm 0.3 \mathrm{mmol} / \mathrm{l}$, respectively; $P=0.7$ ), triglycerides $(0.3 \pm 0.1$ compared to $0.4 \pm 0.1 \mathrm{mmol} / 1$, respectively; $P=0.3)$, and NEFA $(0.6 \pm 0.4$ compared to $0.8 \pm 0.6 \mathrm{mmol} / \mathrm{l}$, respectively; $P=0.1$ ) before the breeding period. NEFA values of both groups showed evidence of negative energy balance. The nutritional state of alpacas before the breeding period did not explain the differences obtained in their reproductive success.

Key words: nutrition, fertility, camelids.
\end{abstract}

\section{INTRODUCTION}

South American camelids (Family Camelidae) live above 3,000 masl in an ecosystem called the Puna, foraging on plant formations such as tolar, bofedal, and pajonal. The Puna is characterised by a wet season in which $95 \%$ of the annual precipitations are concentrated (December to March), when the grazing reaches the highest levels of quality and quantity. During the dry season (April to November) the dry matter produced per Ha is close to half the amount produced during the wet season (Castellaro et al 2004).

Domestic South American camelids (llama and alpacas) are both, induced ovulators and uniparous species. In the Puna, their breeding and parturition are restricted to the wet season, while gestation and lactation last 11.5, and nine months, respectively (San Martín 1996, Vaughan 2011). Several studies have reported low fertility of Puna herds (less than 50\%). A birth rate of $40-60 \%$ has been described in Chile (FAO 2005), and an embryonic mortality rate of $45-56 \%$ has been determined in herds from Peru (Fernández-Baca et al 1970, Bravo and Sumar 1985, Ratto et al 2011). Low fertility rates are partly attributable to high embryonic mortality and reproductive mismanagements, and especially to the poor nutritional state of the livestock: the high nutritional demand for fetal growth

\footnotetext{
Accepted: 18.10.2017.

a School of Veterinary Medicine, Faculty of Natural Resources, Universidad Católica de Temuco, Chile.

bNúcleo de Investigación en Producción Alimentaria (NIPA), Universidad Católica de Temuco, Temuco, Chile.

*Corresponding author: C Norambuena; Manuel Montt 056, Temuco, PC 4780000, Chile; mcnorambuena@uct.cl
}

coincides with a critical period of nutrient deficiency (Van Saun 2008, San Martin and Van Saun 2014). In Chile, the recommendations to breed wild vicuñas include having a body live weight over $40 \mathrm{~kg}$ to reduce the risk of winter abortion (Ellmen 2004, Raggi and Parraguez 2005).

Energy imbalance in ruminant species can cause a sub-fertility syndrome with abnormal oestral behaviour, prolonged post-partum anoestrus, low conception rate, increase in embryo mortality and retarded involution of the uterus (Diskin et al 2003, Patton et al 2007). Thus, reproduction is sensitive to changes in the availability of nutrients and energy through direct and complex interactions of different hormones, metabolites and neuropeptides such as leptin, ghrelin, insulin-like growth factor-1, insulin, glucagon, growth hormone, glucose and neuropeptide $\mathrm{Y}$ (Schneider 2004, Webb et al 2004). It has been described in camelids that llamas under chronic nutritional restriction had small dominant follicles and corpus luteum, and lower progesterone secretion (Norambuena et al 2013).

The aim of this study was to determine the relationship between the nutritional state of alpacas before the breeding period with their reproductive success.

\section{MATERIAL AND METHODS}

The study was authorised by the bioethics committee of the Universidad Católica de Temuco. Thirty-five nonpregnant, non-lactating female alpacas from a herd located in the village of Caquena ( $18^{\circ} 03^{\prime} \mathrm{S} ; 6^{\circ} 11^{\prime} \mathrm{W} ; 4405 \mathrm{~m}$.), Arica and Parinacota Region of Chile, were studied. The herd of about 400 alpacas maintains year-round males and females grazing together in the Caquena bofedal. The reproductive state of alpacas was determined using rectal palpation and trans-rectal ultrasonography with a linear 
probe $(7.5 \mathrm{MHz}$, Samsung Madison, Korea) to identify the presence of an echogenic embryo or fetus, and it took place in October 2015, previous to the breeding period. Lactation was excluded by palpation of the mammary gland and age was determined using dental chronometry. The alpacas body live weight (BLW) were obtained using a mechanical scale $( \pm 0.1 \mathrm{~kg})$, and the body condition score (BCS) was determined according to Van Saun (2009). A blood sample was taken ( $4 \mathrm{ml}$; heparinised tubes) from the jugular vein to determine the plasma concentration of cholesterol (CHODPAP method; HUMAN ${ }^{\circledR}$ ), non- esterified fatty acids (enzymatic colorimetric method; RANDOX ${ }^{\circledR}$ ) and triglycerides (GPO-PAP method; HUMAN ${ }^{\circledR}$ ). The samples were centrifuged immediately at $1500 \mathrm{x} g$ for 15 minutes; plasma was transported by plane to Universidad Católica de Temuco, where it was stored at $-80^{\circ} \mathrm{C}$. Protein and metabolites were analysed using a Metrolab 2300 Plus, Random Access Clinical Analyzer (Wiener Lab, Argentina), at the Veterinary Sciences Laboratory, Universidad Católica de Temuco, Chile. Following the breeding period (May 2016), pregnancy was determined by rectal palpation and trans-rectal ultrasonography and animals were assigned to the Pregnant or Non-pregnant groups. The Shapiro-Wilks test was used to determine the normal distribution of the data and the Levene's test to determine the homoscedasticity of the variances. Data from both groups were compared using the Mann-Whitney U test, using the SPSS V. 20.0 statistic programme (SPSS Inc, Chicago IL, USA) with a $P<0.05$ significance level.

\section{RESULTS AND DISCUSSION}

Twenty alpacas out of $35(57 \%)$ were pregnant at the end of the breeding period. However, it is possible that some pregnant females had not been identified because pregnancy can be positively diagnosed by trans-rectal ultrasound from day 20 in camelids (Herrera et al 2002). The Pregnant and Non-pregnant groups were similar in age, BLW, BCS and plasma concentration of cholesterol, triglycerides, and NEFA, before the breeding period (table 1).

The BLW of animals agrees with that obtained in Chilean herds (Raggi et al 1997, Muñoz 2007). Age did not differentiate groups; animals ranged from 1 year 10 months to 3 years 10 months before the breeding period. Alpaca females are usually first bred at 12 months of age, but many breeders delay their first breeding until 15-18 months old (Vaughan and Tibary 2006), which was the age of the youngest alpacas during the breeding period of this study. The BCS of the groups indicates an ideal fat cover (Van Saun 2009) which was not expected, considering that the critical levels of forage quality and productivity extended from June to October in the Chilean Puna (Raggi and Parraguez 2005). The mean BCS of both groups was according the mating recommendation for small ruminant species (3-3.5 BCS), (Molina et al 1994, Vatankhah et al 2012).

Both groups had similar plasma concentrations of cholesterol, triglycerides and NEFA prior to the breeding period, thus indicating that energy metabolic status does not explain the differences obtained in their reproductive success. The plasma concentrations of cholesterol and triglycerides were within the reference intervals for adult alpacas (table 1). However, Siguas et al (2007) obtained lower values than our study in plasma concentrations of triglycerides during the dry season $(0.1 \pm 0.06 \mathrm{mmol} / \mathrm{l})$ and the wet season $(0.08 \pm 0.04 \mathrm{mmol} / \mathrm{l})$ in alpacas from the Peruvian Puna; probably due to a lower lipid intake from their forage (Aboelmaaty et al 2008). The NEFA levels were in the upper limit of the reference interval obtained

Table 1. Age and nutritional variables values (mean $\pm \mathrm{SD}$, range) from non-pregnant alpacas $(\mathrm{n}=35)$ before the breeding period. Pregnancy diagnosis was carried out at the end of the breeding period.

\begin{tabular}{|c|c|c|c|c|}
\hline \multirow{2}{*}{ Variable } & \multirow{2}{*}{$\begin{array}{l}\text { Pregnant group } \\
\quad(\mathrm{n}=20)\end{array}$} & \multirow{2}{*}{$\frac{\text { Non-pregnant group }}{(\mathrm{n}=15)}$} & \multirow{2}{*}{$\mathrm{P}$} & \multirow{2}{*}{ References intervals } \\
\hline & & & & \\
\hline$\overline{\text { Age }}$ & $30 \pm 7(22-46)$ & $31 \pm 7(22-46)$ & 0.6 & \\
\hline \multicolumn{5}{|l|}{$(\mathrm{m})$} \\
\hline BLW & $47 \pm 9(35-67)$ & $53 \pm 11(35-70)$ & 0.1 & \\
\hline \multicolumn{5}{|l|}{$(\mathrm{kg})$} \\
\hline BCS & $3.0 \pm 0.4(2.5-4)$ & $3.1 \pm 0.4(2.5-4)$ & 0.5 & \\
\hline \multicolumn{5}{|l|}{$(1-5)$} \\
\hline Cholesterol & $1.0 \pm 0.4(0.5-1.8)$ & $0.9 \pm 0.3(0.5-1.6)$ & 0.4 & 0-1.5 mmol/l (Fowler 1998) \\
\hline$(\mathrm{mmol} / \mathrm{l})$ & & & & $0.2-2.2 \mathrm{mmol} / \mathrm{l}$ (Foster et al 2009) \\
\hline Triglycerides & $0.3 \pm 0.1(0.2-0.5)$ & $0.4 \pm 0.1(0.2-0.5)$ & 0.8 & 0.1-0.5 mmol/1 (Foster et al 2009) \\
\hline$(\mathrm{mmol} / \mathrm{l})$ & & & & 0-0.5 mmol/l (Husakova et al 2014) \\
\hline $\begin{array}{l}\text { NEFA } \\
(\mathrm{mmol} / \mathrm{l})\end{array}$ & $0.6 \pm 0.4(0.2-1.4)$ & $0.8 \pm 0.6(0.2-1.5)$ & 0.1 & 0.1-0.7 mmol/l (Husakova et al 2014) \\
\hline
\end{tabular}

BLW = body live weight; $\mathrm{BCS}=$ body condition score; NEFA = non- esterified fatty acids; $P$ values of Mann-Whitney U test. 
in alpacas from to Central Europe farms (Husakova et al 2014). Indeed, the non-pregnant group slightly exceeded this range. The fat mobilization increased NEFA in camelids (Tornquist et al 2001, Norambuena et al 2013) with values about $2 \mathrm{mmol} / \mathrm{l}$ in llamas submitted to five days of fasting (Wenswoort et al 2001). In addition, the NEFA values obtained in this study were very similar to those obtained in pregnant vicuñas (Vicugna vicugna) in their last third of gestation, in the same geographical area (Mussa 2017). Nevertheless, it is necessary to have a reference range of alpacas NEFA from hypoxic environments, since it has been determined that the magnitude of their feed fermentation was grater at high altitude than at sea level (San Martin and Bryant 1989).

In conclusion, the nutritional status obtained before the breeding period did not explain the differences in the reproductive success obtained in alpacas from the Chilean Puna. Further investigations are needed to determine other possible causes behind low fertility indices, such as malnutrition events or drinking water shortages during the breeding period, low male/female ratio, particularities of sexual behaviour and infectious or genetic reproductive pathologies.

\section{ACKNOWLEDGEMENTS}

Fondecyt/Initiation (Dra. Norambuena). Grant $N^{\circ} 11130206$, Government of Chile.

\section{REFERENCES}

Aboelmaaty AM, Mansour MM, Ezzo OH, Haman AM. 2008. Some reproductive and metabolic response to food restriction and re-feeding in Egyptian native goats. Global Veterinaria 22, 225-232.

Bravo PW, Sumar J. 1985. Factors that determine fertility in alpacas. In: Proceedings of the International Convention on SAC, Cusco, Perú.

Castellaro G, Raggi AS, Ullrich RT, Wackwitz B. 2004. Variación estacional de la composición botánica de la dieta de alpacas (Lama pacos Linn.) y llamas (Lama glama Linn.) en praderas altiplánicas de un sector de la provincia de Parinacota, Chile. Agric Tec 64, 353-364.

Diskin MG, Mackey DR, Roche JF, Sreenan JM. 2003. Effects of nutrition and metabolic status on circulating hormones and ovarian follicle development in cattle. Anim Reprod Sci 78, 345-370.

Ellmen E. 2004. Efecto de la suplementación alimentaria estratégica sobre la eficiencia reproductiva en vicuñas mantenidas en semicautiverio. Memoria de Título, Facultad de Ciencias Veterinarias y Pecuarias, Universidad de Chile, Chile.

FAO, Food and Agriculture Organization of the United Nations. 2005. Situación actual de los Camélidos Sudamericanos en Chile. Proyecto de Cooperación técnica en la crianza y aprovechamiento de los Camélidos Sudamericanos en la Región altoandina. TCP/ RLA/2914. Chile. Pp 68.

Fernández-Baca S, Novoa C, Sumar J. 1970. Embryonic mortality in the alpaca. Biol Reprod 3, 243-251.

Foster A, Bidewell C, Barnett J, Sayers R. 2009. Haematology and biochemistry in alpacas and llamas. In practice 31, 276-281.

Fowler M. 1998. Medicine and Surgery of South American Camelids: llama, alpaca, vicuña, guanaco. $2^{\text {nd }}$ ed. Iowa State University Press, Iowa, USA.

Herrera E, Riquelme RA, Sanhueza EM, Raggi LA, Llanos AJ. 2002. Use of fetal biometry to determine fetal age in late pregnancy in llamas. Anim Reprod Sci 74, 101-109.
Husakova T, Pavlata L, Pechova A, Hauptmanova K, Pitropovska E, et al. 2014. Reference values for biochemical parameters in blood serum of young and adult alpacas (Vicugna pacos). Animal 8, 1448-1455.

Molina A, Gallego L, Torres A, Vergara H. 1994. Effect of mating season and level of body reserves on fertility and prolificacy of Manchega ewes. Small Ruminant Res 14, 209-217.

Muñoz J. 2007. Caracterización morfométrica de un rebaño de alpacas huacaya. Tesis, Facultad de Ciencias Veterinarias y Pecuarias, Universidad de Chile, Santiago, Chile.

Mussa K. 2017. Estado nutricional de vicuñas (Vicugna vicugna) gestantes y no gestantes, dentro y fuera de la estación reproductiva en el altiplano chileno. Tesis, Universidad Católica de Temuco, Temuco, Chile.

Norambuena MC, Silva M, Urra F, Ulloa-Leal C, Fernández A, et al. 2013. Effects of nutritional restriction on metabolic, endocrine, and ovarian function in llamas. Anim Reprod Sci 138, 252-260.

Patton J, Kenny DA, McNamara S, Mee JF, O`Mara FP, et al. 2007. Relationship among milk production, energy balance, plasma analytes, and reproduction in Holstein-Frisian Cows. J Dairy Sci 90, 649-658.

Raggi LA, Mac Niven V, Rojas R, Castellaro G, Zolezzi M, et al. 1997. Caracterización de la ganancia de peso de alpacas (Lama pacos) desde el nacimiento y hasta los 6 meses de edad en cuatro regiones de Chile. Agro Sur 25, 219-226.

Raggi LA, Parraguez VH. 2005. Manejo reproductivo de la vicuña. In: Galaz J, González G (eds). Técnicas de Manejo Productivo de la Vicuña (Vicugna Vicugna, Molina, 1782) en Chile. Corporación Nacional Forestal y Fundación para la Innovación, Santiago, Chile, Pp 209-221.

Ratto M, Cervantes M, Norambuena MC, Silva M, Miragaya M, et al. 2011. Effect of location and stage of development of dominant follicle on ovulation and embryo survival rates in alpacas. Anim Reprod Sci 127, 100-105.

San Martín F, Bryant FC. 1989. Nutrition of domestic South American llamas and alpacas. Small Ruminant Res 2, 191-216.

San Martín F. 1996. Nutrición de los camélidos sudamericanos y su relación con la reproducción. Rev Argentina Prod Anim 16, 305-312.

San Martín F, Van Saun R. 2014. Feeding management systems. In: Cebra C, Anderson DE, Tibary A, Van Saun RJ, Johnson LW (eds). Alpaca and Llama Care. Elsevier Inc, Philadelphia, PA, USA, Pp 91-100.

Schneider J. 2004. Energy balance and reproduction. Physiol Behav 81, 289-317.

Siguas O, Paucar R, Olazabal J, San Martín F, Vélez V. 2007. Valores Bioquímicos sanguíneos en alpacas en dos épocas del año en condiciones de Huancavelica: Aportes al perfil metabólico de la especie. $V$ Congreso Internacional de Ganadería de Doble Propósito, Cusco, Perú, Pp 32-36.

Tornquist C, Cebra C, Van Saun R, Smith B, Matoon S. 2001 Metabolic changes and induction of hepatic lipidosis during feed restriction in llamas. Am J Vet Res 62, 1081-1087.

Van Saun R. 2008. Effect of nutrition on reproduction in llamas and alpacas. Theriogenology 70, 508- 514.

Van Saun R. 2009. Feeding fundamentals for South American camelids. Vet Clin Food Anim 25, 265-279.

Vaughan J, Tibary A. 2006. Reproduction in female South American camelids: A review and clinical observations. Anim Reprod Sci $61,259-281$

Vaughan J. 2011. Ovarian function in South American camelids (alpacas, llamas, vicunas, guanacos). Anim Reprod Sci 124, 237-243.

Vatankhah M, Talebi MA, Zamani F. 2012. Relationship between ewe body condition score (BCS) at mating and reproductive traits in Lori-Bakhtiari sheep. Small Ruminant Res 106, 105-109.

Webb R, Garnsworthy P, Gong J, Amstrong D. 2004. Control of follicular growth: local interactions and nutritional influences. J Anim Sci 82, E63-E74.

Wenswoort J, Kyle D, Orskov E, Bourke D. 2001. Biochemical adaptation of camelids during periods where feed is withheld. Rev Rangifer 21, 45-48. 
